\title{
PENDAMPINGAN PENYUSUNAN ARTIKEL ILMIAH BAGI GURU SEKOLAH MENENGAH KEJURUAN DI JAWA TENGAH
}

\author{
Hasan Mukhibad $^{1)}{\text {; } \text { Asrori }^{2)} \text {; Prabowo Yudo Jayanto }}^{\text {3) }}$ \\ 1, 2,3) Jurusan Akuntansi, Fakultas Ekonomi, Universitas Negeri Semarang \\ ${ }^{1)}$ Email: hasanmukhibad@mail.unnes.ac.id
}

\begin{abstract}
Abstrak
Masalah yang masih dihadapi oleh guru adalah rendahnya kemampuan dalam menyusun artikel ilmiah yang dipublikasikan jurnal ilmiah. Tujuan dari kegiatan ini adalah melakukan pendampingan guru dalam menyusun artikel ilmiah. Untuk menyelesaikan permasalahan ini, perlu dilakukan pelatihan dan pendampingan guru dalam menyusun artikel ilmiah. Metode pendampingan adalah dengan melakukan pelatihan dan pendampingan guru dalam menyusun artikel ilmiah. Keberhasilan atas kegiatan ini akan dievaluasi dengan membandingkan pre-test dan post-test dan dianalisis menggunakan paired simple T-test. Hasil kegiatan menunjukkan bahwa respon guru dalam pelaksanaan kegiatan ini sangat baik. Selain itu, hasil uji perbedaan antara nilai pre-test dan post-test menunjukkan adanya perbedaan yang signifikan dan ini menunjukkan bahwa terdapat peningkatan pemahaman guru terkait dengan artikel ilmiah dan jurnal ilmiah. Saran dari kegiatan ini adalah dapat dilakukan pelatihan lanjutan yang dilakukan secara intesif dengan melibatkan organisasi keguruan, sekolah, dinas pendidikan dan universitas.
\end{abstract}

Kata Kunci: Artikel, jurnal Ilmiah, guru, penelitian

\begin{abstract}
The problem that is still faced by teachers is the low ability of teachers to compile scientific articles published in scientific journals. The purpose of this activity is to assist teachers in compiling scientific articles. To solve this problem, it is necessary to train and mentor teachers in compiling scientific articles. The mentoring method is to conduct training and mentoring teachers in compiling scientific articles. The success of this activity will be evaluated by comparing the pre-test and post-test and analyzed using the paired simple T-test. The results of the activity showed that the teacher's response in the implementation of this activity was very good. In addition, the results of the difference test between the pre-test and post-test scores showed a significant difference and this indicated that there was an increase in teacher understanding regarding scientific articles and scientific journals. The suggestion from this activity is that further training can be carried out intensively by involving teacher organizations, schools, education offices and universities.
\end{abstract}

Keywords: Manuscript, scientific journals, teachers, research.

\section{PENDAHULUAN}

Peningkatan kualitas guru dalam menulis karya Ilmiah telah menjadi sorotan pemerintah akhir-akhir ini. Hal ini terwujud dari munculnya aturan bahwa guru diharuskan memiliki karya ilmiah sebagai syarat kenaikan pangkat sebagaimana tercantum pada Permen PAN dan Reformasi Birokrasi Nomor 16 Tahun 2009. Pada awalnya, kewajiban menyusun karya ilmiah ditujukan untuk kenaikan pangkat golongan minimal IV-c, namun peraturan baru mewajibkan untuk kenaikan pangkat minimal mulai IIIb.
Dalam Pasal 9 ayat 2 Untuk kenaikan pangkat/jabatan setingkat lebih tinggi menjadi Pembina Tk.I, golongan ruang IV/b/Guru Pembina Tk.I sampai dengan Pembina Utama, golongan ruang IV/e/Guru Utama, diwajibkan mengumpulkan sekurang- kurangnya 12 (dua belas) angka kredit dari unsur pengembangan profesi. Pasal 10 ayat 1 Guru yang berkolaborasi menyusun karya tulis/karya ilmiyah di bidang pendidikan, pembagian angka kredit ditetapkan sebesar $60 \%$ (enam puluh persen) bagi penulis utama, dan $40 \%$ (empat puluh persen) bagi semua penulis pembantu. Dari peraturan Kepmenpan No. 84/1993, seorang guru sangat penting untuk 
mempubliskan karya ilmiahnya dalam jurnal ilmiah. Publikasi ini selain untuk kenaikan pangkat juga sebagai media dalam mengembangkan profesi guru.

Kebijakan ini cukup beralasan karena guru pendidik diharuskan untuk selalu meningkatkan keilmuannya, salah satunya dengan menyusun karya ilmiah. Pada dasarnya guru dalam menjalankan profesinya, seringkali berhadapan dengan masalah pengajaran. Masalah pengajaran in dapat menjadi bahan bagi guru untuk memecahkannya dengan penelitian, perumusan metode pembelajaran baru, atau penerapan metode pembelajarn baru. Upaya ini dapat menjadi salah satu bahan bagi guru untuk mempublikasikan hasil penelitiannya dalam karya ilmiah.

Handayani \& Rukmana (2020) berpendapat bahwa penelitian dilakukan agar guru dapat terus menjaga kualitas pembelajaran di sekolah dengan melakukan kajian, menciptakan inovasi dan melakukan berbagai perubahan di dalam proses pembelajaran di kelas. Salah satu metode yang dapat dilakukan oleh guru adalah dengan melakukan Penelitian Tindakan Kelas (PTK) (Handayani \& Rukmana, 2020). Putra \& Saputra (2019) menilai bahwa kegiatan publikasi ilmiah adalah salah satu bentuk upaya untuk memperbaharui mental. Dengan demikian, penulisan artikel tidak bisa dilepaskan dari tugas guru (Gunawan, Triwiyanto, \& Kusumaningrum, 2018).

Fakta yang ada menunjukkan bahwa guru masih mengalami kendala dalam menyusun karya ilmiahnya (Ulia, Ismiyanti, Yustiana, \& Cahyaningtyas, 2019). Zahera (1997) dan Ritonga \& Iskandar (2018) mengungkapkan bahwa guru yang tidak mengajukan kenaikan kepangkatan karena terkendala dalam menyusun karya Ilmiah. (Miaz, Zuardi, \& Putra, 2020) menemukan bahwa banyak guru yang tidak melanjutkan kenaikan pangkat ke IV-b dikarenakan guru tidak melaporkan PTK yang dilakukan. Ini artinya bahwa sebenarnya guru telah mampu melaksanakan penelitian, namun belum mampu melaporkan hasil penelitiannya dalam bentuk artikel ilmiah.

Berdasarkan analisis situasi di atas, dapat ditarik kesimpulan sementara bahwa guru sudah mampu melaksanakan penelitian. Namun guru belum mampu melaporkan hasil penelitiannya pada artikel ilmiah. Untuk itu, diperlukan kegiatan dan pendampingan guru dalam menyusun karya ilmiah. Kegiatan pelatihan dan pendampingan ini difokuskan pada guru Sekolah Menengah Kejuruan (SMK). Alasannya adalah guru SMA memiliki kemampuan dalam menyusun karya ilmiah lebih daripada guru SMK (Rochmad, Agoestanto, \& Kharis, 2016). Selain itu, guru SMK juga mengalami kendala dalam menulis (Chairunnisa, 2016) dan penyusunan artikel ilmiah (Karwan \& Hariri, 2020). Pada kegiatan ini, kegiatan akan dimulai dengan pengenalan tentang jurnal ilmiah, pelaksanaan penelitian dan strategi penyusunan artikel ilmiah.

\section{Permasalahan Mitra}

Berdasarkan analisis situasi di atas, ditemukan bahwa guru masih mengalami kendala dalam menyusun artikel ilmuah, termasuk adalah guru SMK (Munasir, Jatmiko, Dwikoranto, \& Rasid, 2020; Arta, 2018; Usra, Hartati, \& Destriani, 2018). Guru telah yang telah menyelesaikan studi sarjana pada dasarnya telah mampu melaksanakan penelitian, namun belum mampu melaporkannya dalam karya ilmiah (Handayani \& Rukmana, 2020). Akibat dari masalah ini adalah terkendalanya pengajukan kepangkatan guru karena tidak mempu memenuhi persyaratan karya ilmiah. (Munasir et al., 2020) menemukan bahwa $87,7 \%$ guru tidak memenuhi syarat kenaikan pangkat karena karya ilmiah yang diajukan tidak memenuhi syarat penulisan ilmiah yang baik. (Arta, 2018) melakukan wawancara dengan guru untuk mengindentifikasi penyebab guru memiliki kemampuan menulis karya ilmiah yang rendah dan menemukan bahwa rendahnya kemampuan ini karena :

1. Kurangnya pengetahuan, pemahaman, dan keterampilan guru dalam menulis artikel ilmiah,

2. Terbatasnya sumber bacaan berupa karya ilmiah yang dapat diakses oleh guru,

3. Sekolah dan dinas pendidikan belum memiliki majalah atau jurnal ilmiah yang dapat menampung tulisan para guru,

4. Minimnya lomba lomba menulis karya ilmiah bagi guru, dan 
5. Rendahnya motivasi guru untuk mengikuti lomba menulis karya ilmiah.

Sementara itu, (Sumardjoko, 2017) melakukan pemetaan terhadap guru dan menemukan bahwa di Propinsi Jawa Tengah, 60\% guru Pegawai Negeri Sipil (PNS) yang telah mencapai golongan ruang IVa tidak dapat naik pangkat setingkat lebih tinggi karena terkendala dalam penulisan karya ilmiah. Selain itu, (Sumardjoko, 2017) juga menemukan sebanyak 55\% guru merasa kurang paham dengan karya ilmiah dan 30\% merasa tidak paham dengan karya ilmiah. Permasalahan rendahnya kemampuan guru dalam mengusun karya ilmiah juga terjadi pada guru SMK (Karwan \& Hariri, 2020; Chairunnisa, 2016; Rochmad et al., 2016).

Untuk menyelesaikan masalah in, perlu dilakukan pelatihan dan pendampingan guru dalam menyusun artikel ilmiah. Pendampingan dimulai dari pengenalan artikel ilmiah, pemilihan jurnal, penulisan manuscript dan selanjutnya bagaimana cara men-submit artikel melalui Online Journal System (OJS).

\section{METODOLOGI PENGABDIAN}

Kegiatan ini dilakukan dengan metode ceramah, diskusi, serta praktek penyusuna artikel ilmiah serta praktek submit artikel ilmiah. Adanya kendala pandemi menyebabkan pelaksanaan kegiatan ini dilakukan secara daring. Peserta dapat dilakukan secara sukarela oleh seluruh guru SMK di Jawa Tengah dan telah diikuti oleh 183 peserta.

Secara rinci, metode pelaksanaan kegiatan ini dijelaskan pada Gambar 1.

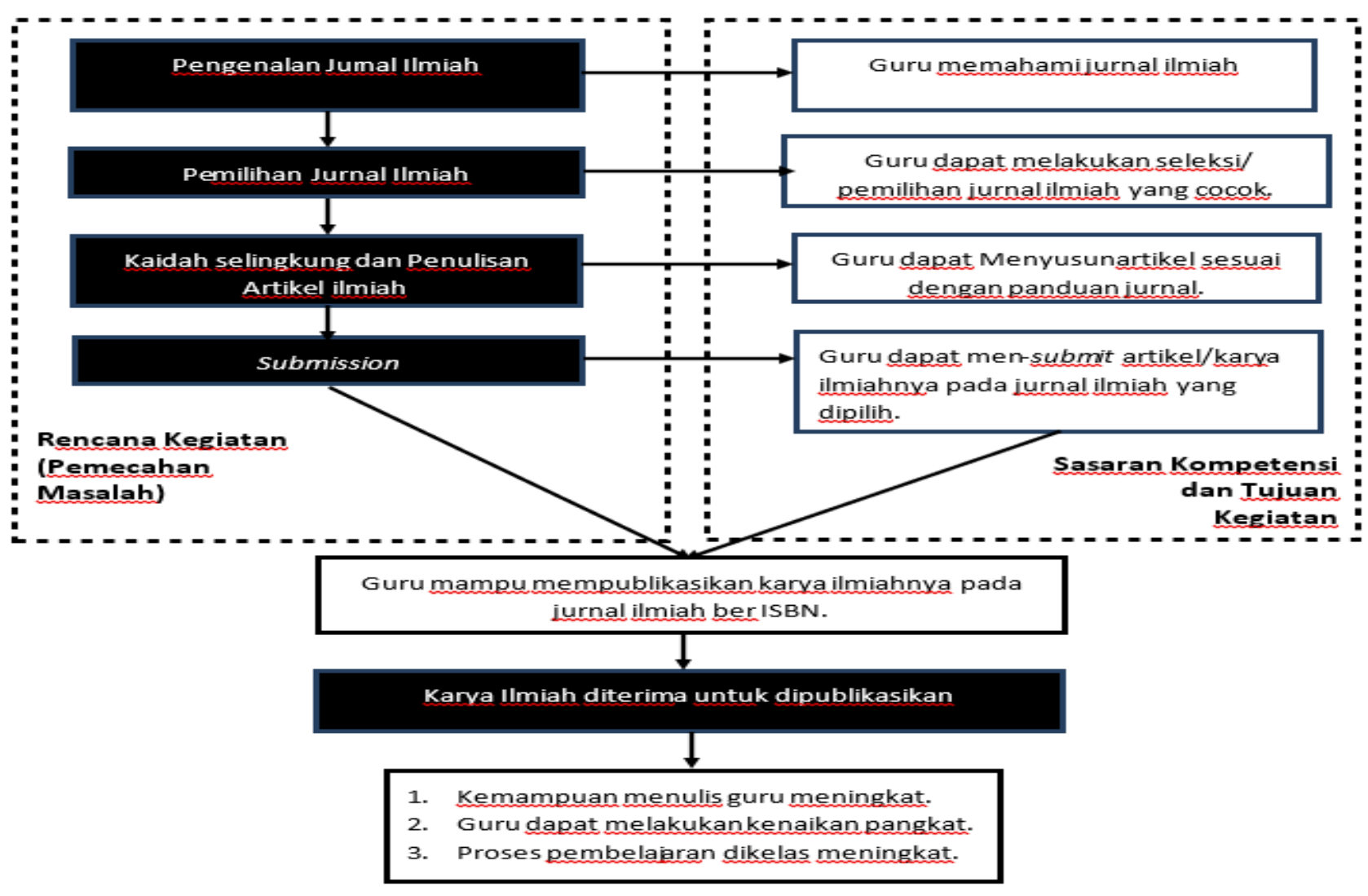

Gambar 1. Metode pelaksanaan pengabdian

Untuk melihat efektifitas dari Kegiatan ini juga dilakukan menyebarkan kuesioner terkait dengan kemampuan guru dalam menyusun karya ilmiah sebelum dilakukan kegiatan (pre-test) dan setelah dilaksanakan kegiatan (post-test). Nilai ini kemudian dilakukan uji beda dengan paired t-test. Hasil kegiatan dapat dikatakan efektif ketika terdapat perbedaan yang signifikan antara nilai 
pre-test dan post-test dengan memperhatikan nilai signifikansi Paired Samples Correlations, dimana jika nilai signifikansi lebih dari 0.05 memberikan kesimpulan bahwa tidak terdapat perbedaan nilai pre-test dan post-test. Sebaliknya, jika nilai signifikansi kurang dari 0.05 memberikan kesimpulan bahwa terdapat perbedaan nilai pretest dan post-test. Alat statistik berupa Statistical Product and Service Solutions (SPSS) diperlukan untuk melakukan uji beda ini.

\section{PELAKSANAAN KEGIATAN}

Kegiatan pengabdian ini telah dilaksanakan melalui daring. Waktu pelaksanaan kegiatan ini adalah sebagai berikut ini:

$\begin{array}{ll}\text { Hari } & : \text { Rabu } \\ \text { Jam } & : 09.00 \text { sd } 12.00 \text { WIB } \\ \text { Tanggal } & : \text { 15 Juli } 2020\end{array}$

Kegiatan ini mendapat respon baik dari peserta. Hal ini terlihat dari banyaknya peserta yang mendaftar sebagai peserta, yakni sebanyak kurang lebih 183 peserta. Untuk mengefektifkan kegiatan, maka panitia juga menyiarkan langsung kegiatan ini dalam bentuk live streaming melalui youtube channel yang dimiliki oleh jurusan akuntansi, Fakultas Ekonomi, Universitas Negeri Semarang.

Pembicara adalah sebagai berikut ini:

1. Dr. Agus Wahyudin, M.Si dengan tema Metodologi Penelitian Pendidikan.

2. Hasan Mukhibad, S.E., M.Si dengan tema Tip menyusun artikel ilmiah dan submit pada jurnal ilmiah.

Kegiatan pengabdian ini dilakukan untuk melatih guru dalam melaksanakan penelitian, menuliskan hasil penelitian dan mempublikasikannya dalam artikel ilmiah. Dengan demikian, sedikitnya terdapat tiga subkegiatan yang akan dilakukan pada pengabdian ini.

Sub kegiatan yang pertama adalah pelatihan dalam melaksanakan penelitian. Dalam kegiatan ini, prioritasnya adalah memberikan pelatihan bagi guru terkait dengan perencanaan penelitian, dan pelaksanaan penelitian. Jenis pelatihan yang diberikan adalah penelitian kausalitas dalam pendidikan dan menghiraukan jenis Penelitian Tindakan Kelas (PTK). Alasannya, pelatihan PTK biasa diterima oleh guru. Selain itu, jurnal yang memiliki scope artikel PTK lebih sedikit jumlahnya daripada penelitian non-PTK. Artinya penelitian kausalitas memiliki potensi publish lebih besar daripada penelitian non-PTK.

\section{HASIL DAN PEMBAHASAN}

Pada tahapan ini, diberikan materi tentang pengantar penelitian kausalitas, perencanaan penelitian, dan bagimana melaksanakannya. Pada tahapan pengantar, disajikan jenis-jenis penelitian dan bagaimana perbedaannya. Pada tahapan ini, targetnya adalah peserta mengetahui bagaimana itu penelitian kausalitas dan peserta mampu membedakannya dengan penelitian PTK.

Selanjutnya diberikan pemahaman tentang perencanaan penelitian. Target pada tahapan ini adalah peserta mampu mengidentifikasi topik atau hal dan menemukan masalah yang menjadi dasar dilakukan penelitian. Alasan dilakukan penelitian adalah fenomena gap. Beberapa contoh fenomena gap yang mudah ditemukan disekolah seperti:

a. Rendahnya prestasi siswa

b. Kurang bersaingnya salah satu sekolah terhadap sekolah lainnya.

c. Kemalasan siswa dalam mata pelajaran tertentu

d. Rendahnya peminatan siswa terhadap sekolah tertentu

e. Kualitas guru dalam pembelajaran

Dari permasalahan di atas, penelitian dapat dilakukan dengan mengidentifikasi faktor-faktor yang digunakan oleh peneliti dalam menjelaskan permasalahan penelitian. Pada tahapan ini, peserta melakukan penelusuran penelitian terdahulu yang menjelaskan permasalahan ini. Dari penelitian terdahulu ini, peserta melakukan mengidentifikasi variabel independen yang digunakan penelitian terdahulu dan melakukan peringkasan atas hasil penelitian terdahulu. Dari berbagai variabel independen ini, peserta dapat melakukan pemilihan variabel dengan berdasarkan: konsistensil hasil penelitian, frekuensi penggunaan vaiabel tersebut, kemampuan peneliti untuk mengadopsi.

Tahapan selanjutnya adalah melakukan pengukuran variabel. Tim pengabdi merekomendasikan (pada tahap awal) guru dapat melakukan replikasi bagaimana peneliti sebelumnya mengukur variabel yang digunakan. Pada tahapan mapping artikel, peserta juga 
melakukan mapping atas pengukuran dari variabel yang digunakan.

Tahapan selanjutnya adalah pengolahan data dan penyajian hasil. Pada tahapan ini, tidak banyak yang diberikan karena dalam melakukan pengolahan, peserta diharuskan memahami statistik dan alat analisis. Pelatihan olah data membutuhkan waktu yang tidak sedikit dan harus dilakukan secara offline karena ini harus praktek. Dengan demikian, direkomendasikan untuk menonton youtube bagaimana cara megolah data minimal dengan alat bantu SPSS.

\section{Publikasi Hasil Penelitian}

Setelah penelitian dilaksanakan, tahapan selanjutnya adalah menuliskannya pada artikel ilmiah. Pada tahapan ini, target kegiatan ini adalah peserta mampu menyajikan hasil penelitiannya pada artikel ilmiah yang menarik dan layak untuk dipublikasikan. Pada tahapan ini, ajikan bagaimana cara memilih jurnal ilmiah, dan menuliskannya dalam artikel ilmiah.

Pemilihan jurnal diawali dengan pengenalan indeksasi, terutama indeksasi sinta. Pada laman sinta, terdapat informasi yang dapat diperoleh seperti nama jurnal dan peringkat sinta, serta informasi penerbit. Pemilihan jurnal dilakukan dengan pencarian kata kunci tertentu pada laman SINTA. Kemudian mencari informasi laman jurnal dan selanjutnya membuka jurnal tersebut.

Setelah membuka laman jurnal, hal yang pertama dilakukan adalah membuka menu "scope". Ini digunakan untu memastikan bahwa artikel yang dimiliki memiliki scope yang diterima untuk dipublikasikan pada jurnal sasaran. Jika scope telah memenuhi, langkah selanjutnya adalah mengunduh layout dan membaca kaidah selingkung jurnal. Sesuaikan artikel yang dimiliki dengan kaidah selingkung jurnal dan ditulis pada layout jurnal.

\section{Penyusunan Artikel Ilmiah}

Tahapan ini, tim pengabdi menyampaikan materi tentang hal-hal pokok yang harus disajikan pada sebuah karya ilmiah. Kaidah selingkung yang digunakan adalah kaidah selingkung dasar yang biasanya digunakan dalam penulisan artikel ilmiah.
Kaidah itu antaranya pendahuluan, teori dan pengembangan hipotesis, metode hasil, dan penutup.

Pada bagian pendahuluan, hal yang harus disajikan adalah masalah penelitian, penyajian pemecahan masalah serta perbedaan penelitian ini dengan penelitian sebelumnya.

Bagian selanjutnya adalah teori dan pengembangan hipotesis. Pada bagian ini, hal yang tersampaikan adalah pembahas teori dan pengembangan hipotesis yang diturunkan dari teori dan dari penelitian terdahulu. Selain itu, dibagian ini perlu ditekankan adalah logika dalam menjelaskan hubungan sebab akibat atau hubungan kausalitas antara variabel independent ke variabel dependent.

Bagian selanjutnya adalah metode. Bagian metode ini menjelaskan tentang populasi, sampel dan teknik sampling. Selain itu menyajikan cara mengukur variabel serta alat analisis yang digunakan.

Bagian keempat adalah hasil penelitian. Pada bagian ini, penulis harus menyajikan hasil analisis dekriptif (Rata-rata, Nilai Minimal, Maksimal dan Standar Error) atas semua variabel penelitian. Bagian ini juga menyajikan hasil uji data yang menyangkut hasil uji sebelum melakukan uji hipotesis seperti hasil uji asumsi klasik (jika diperlukan) dan hasil uji hipotesis. Setelah itu, sajikan jawaban atas hipotesis dan berikan pembahasan

Bagian terakhir dari artikel ilmiah adalah penutup. Pada bagian ini, penulis menyajikan kesimpulan hasil penelitia dan saran yang diberikan. Saran yang berikan dapat kepada regulator, pengelola sekolah, dan peneliti selanjutnya.

\section{Evaluasi Hasil Kegiatan}

Evaluasi kegiatan ini dilakukan dengan menyebarkan pertanyaan kepada guru sebelum dilakukan kegiatan pengabdian ini dan setelah guru mengikuti kegiatan pengabdian. Pertanyaan yang diajukan ini berkaitan dengan mengukur pemahaman guru terkait dengan karya ilmiah dan jurnal ilmiah. Hasil pre-test dan post-test terangkum dalam tabel 1 dan 2. 
Tabel 1. Descriptive Statistics

\begin{tabular}{lcccccc}
\hline & N & Min. & Max. & Mean & $\begin{array}{c}\text { Std. } \\
\text { Devia- } \\
\text { tion }\end{array}$ \\
\hline $\begin{array}{l}\text { PRE- } \\
\text { TEST }\end{array}$ & 183 & 2.00 & 8.00 & 5.0273 & 1.12627 \\
$\begin{array}{l}\text { POST- } \\
\text { TEST }\end{array}$ & 183 & 6.00 & 10.00 & 8.0328 & .90117 \\
$\begin{array}{l}\text { Valid N } \\
\text { (listwise) }\end{array}$ & 183 & & & & \\
\hline
\end{tabular}

Tabel 1 menunjukkan bahwa nilai rata-rata pretest sebesar 5,0273 dan post-test sebesar 8,0328. Hal ini menunjukkan bahwa setelah mengikuti kegiatan ini, pemahaman guru terhadap karya ilmiah dan jurnal ilmiah mengalami peningkatan. Selain itu, nilai standar deviasi antara pre-test dan post-test juga menunjukkan bahwa setelah kegiatan, pemahaman guru menjadi lebih seragam daripada sebelum mengikuti kegiatan ini.

Tahapan selanjutnya adalah melakukan uji beda dari nilai pre-test dan post-test. Uji perbedaan ini dilakukan dengan metode Paired Samples Correlations dengan alat bantu SPSS. Hasil uji ini tersaji pada tabel 2 berikut ini:

Tabel 2. Paired Samples Correlations

\begin{tabular}{llrrr}
\hline & & N & Correlation & Sig. \\
\hline Pair 1 & $\begin{array}{l}\text { pre \& } \\
\text { post }\end{array}$ & 183 & .226 & .002 \\
\hline
\end{tabular}

Tabel 2 menunjukkan bahwa uji Paired Samples Correlations menghasilkan nilai signifikansi sebesar 0,002. Nilai signifikansi yang dihasilkan kurang dari 0,05. Hal ini mengindikasikan bahwa terdapat perbedaan yang signifikan antara nilai pre-test dan post-test. Jika dilihat nilai rata-rata, terlihat bahwa nilai post-test menghasilkan nilai rata-rata yang lebih besar daripada pre-test. Dengan demikian dapat disimpulkan bahwa kegiatan ini menghasilkan kenaikan kemampuan guru terhadap pemahaman tentang artikel ilmiah dan jurnal ilmiah yang signifikan. Selain itu, hasil uji ini menunjukkan bahwa kegiatan ini telah berjalan secara efektif.
Hasil wawancara dengan perwakilan peserta yang memiliki nilai post-test rendah, mereka merasa bahwa pelaksanaan kegiatan ini kurang efektif mengingat materi seperti ini harusnya dilakukan secara intensif dan tidak melalui daring. Peserta mengaku bahwa cukup sulit dalam waktu yang terbatas untuk memahami semua materi. Walaupun semua peserta memiliki latar belakang pendidikan minimal sarjana, namun perlu pemahaman kembali tentang metode penelitian. Peserta kurang memehami tentang penyusunan artikel ilmiah, jika memiliki pemahaman yang kurang baik terhadap metode penelitian.

Peserta mengharapkan ada tindaklanjut dalam kegiatan ini dan ada pendampingan guru dalam penyusunan artikel. Pendampingan diharapkan dari proses penelitian, penyusunan artikel ilmiah dan proses publikasi.

\section{Ucapan Terima Kasih}

Terimakasih Kepada Fakultas Ekonomi, Universitas Negeri Semarang yang telah membiayaai kegiatan ini dengan Surat Perjanjian Pengugasan Pelaksanaan Pengabdian Kepada Masyarakat Dana DIPA UNNES Tahun 2020 Nomor 30.4.5/UN37/PPK.4.7/2020, Tanggal 4 Mei 2020.

\section{PENUTUP}

\section{Kesimpulan}

Pelaksanaan kegiatan ini direspon positif oleh guru. Hal ini terbukti dengan banyaknya peserta yang mengukuti kegiatan ini. Kegiatan ini memberikan pemahaman kepada peserta tentang pelaksanaan penelitian, penulisan artikel ilmiah dan mempublikasikannya dalam artikel ilmiah. Secara umum, dengan membandingkan dan melakukan uji perbedaan antara nilai pre-test dan post-test menunjukkan bahwa kegiatan ini telah efektif dalam meningkatkan pemahaman guru terkait dengan karya ilmiah dan jurnal ilmiah. Selain itu, seluruh kegiatan yang direncanakan telah terlaksana dengan baik. Namun, dari perwakila peserta yang memiliki nilai rendah, mereka merasa bahwa mereka belum memahami dengan baik karena pelaksanaan kegiatan yang dilakukan secara daring. Peserta menginginkan 
kegiatan seperti ini dilakukan secara intensif beserta pendampingan dalam proses pelaksanaan penelitian, penulisan artikel dan proses publikasi.

\section{Saran}

Saran dari kegiatan ini adalah dapat dilakukan pelatihan lanjutan yang dilakukan secara intesif serta adanya kegiatan pendampingan. Pelaksanaan kegiatan ini dapat dilakukan oleh masing-masing sekolah maupun dilakukan oleh dinas pendidikan daerah. Untuk itu, disarankan kepada regulator untuk melakukan kegiatan seperti ini untuk peningkatan kualitas guru serta kelancaran guru dalam proses kenaikan pangkatnya. Saran bagi dosen yang memiliki keahlian lain dapat melakukan kegiatan serupa dengan materi penelitian sesuai bidang keahlian masing-masing dosen dan guru. Ini penting agar proses pelatihan menjadi lebih efektif karena dosen menyampaikan contoh-contoh yang mudah dicerna oleh peserta.

\section{DAFTAR PUSTAKA}

Arta, K. S. (2018). Pelatihan Penulisan Artikel Untuk Publikasi Di Jurnal Ilmiah Untuk Meningkatkan Profesionalisme Bagi GuruGuru Di Kecamatan Kubutambahan Kabupaten Buleleng. Seminar Nasional Hukum Dan Ilmu Sosial Ke-2, 146-159. https://doi.org/10.23887/ap.v5i2.17412

Chairunnisa, C. (2016). Pemberdayaan Guru Melalui Pelatihan Penulisan Karya Ilmiah Di Sekolah Menengah Kejuruan. Faktor Jurnal Ilmiah Kependidikan, 3(2), 105-114.

Gunawan, I., Triwiyanto, T., \& Kusumaningrum, D. E. (2018). Pendampingan Penulisan Artikel Ilmiah Bagi Para Guru Sekolah Menengah Pertama. Abdimas Pedagogi Jurnal Ilmiah Pengabdian Kepada Masyarakat, 1(2), 128-135.

Handayani, S. L., \& Rukmana, D. (2020). Peningkatan Kemampuan Menulis Karya Ilmiah Guru Melalui Pelatihan Penelitian Tindakan Kelas bagi Guru SD. Jurnal Publikasi Pendidikan, 10(14), 8-13.

Karwan, D. H., \& Hariri, H. (2020). Pelatihan Penulisan Karya Tulis Ilmiah Sekota
Surabaya.pdf. SAKAI SAMBAYAN - Jurnal Pengabdian Kepada Masyarakat, 4(1), 6671.

Miaz, Y., Zuardi, \& Putra, R. P. (2020). Pelatihan Penulisan Penelitian Tindakan Kelas Untuk Guru Sekolah Dasar. Jurnal Publikasi Pendidikan, 10(1), 19-25.

Munasir, Jatmiko, B., Dwikoranto, \& Rasid, H. (2020). Pelatihan Penulisan Artikel Ilmiah Bagi Guru Sekolah Dasar Se-UPTD Pendidikan Kec. Sawahan Kab. Nganjuk, Jawa Timur. Jurnal ABDI: Media ..., 5(2), 119-125.

Putra, Y. Y., \& Saputra, A. (2019). Workshop Publikasi Artikel Ilmiah dalam Jurnal Nasional Guru SMP Pangkalpinang. Jurnal Pemberdayaan Masyarakat Berkarakter, 2(2), 207-215.

Ritonga, R., \& Iskandar, R. (2018). Penulisan Karya Tulis Ilmiah Bagi Guru Sekolah Dasar

Di Kerawang. Jurnal Pengabdian Masyarakat Ilmu Keguruan Dan Pendidkan, 1(1), 31-38. https://doi.org/https://doi.org/10.31326/jmpikp.v1i01.75

Rochmad, Agoestanto, A., \& Kharis, M. (2016). Meningkatkan Kualitas Penulisan Karya Ilmiah Guru-Guru Sekolah Menengah Atas Di Parakan Temanggung. Rekayasa, 14(1), 61-66.

Sumardjoko, B. (2017). Pemetaan Kemampuan Guru dalam Penulisan Karya Ilmiah. The 5th Urecol Proceeding, (February), 191-196.

Ulia, N., Ismiyanti, Y., Yustiana, S., \& Cahyaningtyas, A. P. (2019). Pendampingan kelompok guru SD di kecamatan Genuk tentang pemahaman metodologi penelitian pendidikan (action research \& experiment) dan penyusunan artikel jurnal. Indonesian Journal of Community Services, 1(1), 32-47.

Usra, M., Hartati, \& Destriani. (2018). Pelatihan Penulisan Artikel Ilmiah Bagi Guru Sekolah Menengah Atas. Prosiding Seminar Nasional Pendidikan "Mengembangkan Kompetensi Pendidik Dalam Menghadapi Era Disrupsi" Kerjasama PGSD-POR UMS, 3(4-5 Desember 2018), 111-116.

Zahera, S. (1997). Hubungan Konsep Diri dan 
Kepuasan Kerja dengan Sikap Guru dalam

Proses Belajar Mengajar. Jurnal Ilmu

Pendidikan, 4(3), 183-194. 